\title{
The first case of Bovicola (Werneckiella) ocellatus (Piaget, 1880) (Phthiraptera: Ischnocera: Trichodectidae) on a donkey (Equus asinus Linnaeus, 1758) in Turkey
}

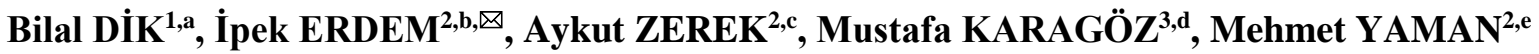 \\ ${ }^{1}$ Selçuk University, Faculty of Veterinary Medicine, Department of Parasitology, Konya; ${ }^{2}$ Hatay Mustafa Kemal University, Faculty \\ of Veterinary Medicine, Department of Parasitology, Hatay; ${ }^{3}$ Ownerless Animal Care and Rehabilitation Center of the Hatay \\ Metropolitan Municipality, Hatay, Turkey. \\ a ORCID: 0000-0002-7553-5611; ' ${ }^{\mathrm{a} O R C I D: ~ 0000-0002-0086-8294 ; ~ ' ~} \mathrm{ORCID}$ : 0000-0002-8533-387X; \\ ${ }^{\mathrm{d} O R C I D:}$ 0000-0003-3977-441X; ' ORCID: 0000-0001-5399-8060
}

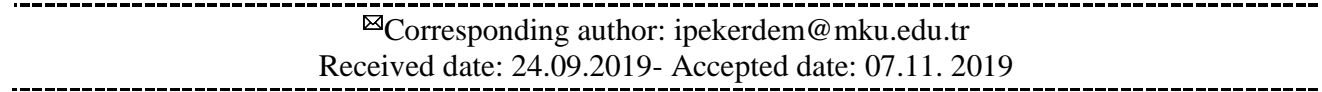

\begin{abstract}
In the clinical examination of a donkey, which brought to the Ownerless Animal Care and Rehabilitation Center of the Hatay Metropolitan Municipality due to neglecting and senility, local hair losses, ruffling and opacity were observed. A few louse specimens were detected on the hair shafts on the back of the donkey during the macroscopic examination. They were collected with a forceps, and preserved in a tube with alcohol 70\%. Then they examined in detail in microscope, and identified as Bovicola ocellatus (Piaget, 1880). The presence of B. ocellatus on donkey has been reported for the first time in Turkey in this paper.
\end{abstract}

Keywords: Bovicola ocellatus, donkey, louse, Turkey

\section{Türkiye'de bir eşekte (Equus asinus Linnaeus, 1758) ilk Bovicola (Werneckiella) ocellatus (Piaget, 1880) (Phthiraptera: Ischnocera: Trichodectidae) olgusu}

Özet: Hatay Büyükşehir Belediyesi Sahipsiz Hayvan Bakım ve Rehabilitasyon Merkezi'ne yaşlılık ve bakımsızlık nedeniyle getirilen bir eşeğin klinik muayenesinde tüylerinin çok karışık ve matlaşmış olduğu, yer yer döküldüğü gözlenmiştir. Yapılan makroskobik incelemede eşeğin sırt bölgesindeki tüylerin dip kısımlarında bir kaç bit saptanmıştır. Bitler bir pens yardımıyla alınmış ve içinde \%70'lik alkol bulunan bir tüpte saklanmıştır. Daha sonra mikroskopta ayrıntılı olarak incelenen örnekler Bovicola ocellatus olarak teşhis edilmiş̧ir. Bu makaleyle B. ocellatus'un Türkiye'deki varlığı ilk kez bildirilmektedir.

Anahtar sözcükler: Bit, Bovicola ocellatus, eşek, Türkiye

The lice are hemimetabolous and obligatory insects. They complete all their life on the hosts. The lice belonging to the Ischnocera and Amblycera suborders are parasitized on mammals and poultry, and they feed on the feathers or hairs of their hosts. Anopluran species has only seen in mammals, they suck blood of their hosts and cause anemia in heavy infestations. The chewing lice belonging to the genus Bovicola, in family Trichodectidae, suborder Ischnocera are found on cattle, sheep, horses, donkeys and deers. These species are similar to each other morphologically and they are specific to their host $(1,2$, 11). The lice complete their development in onemonth average and their lives vary between 1-2 months $(1,2)$. Although they can be observed on the hosts during the year, however, they are seen more common in winter months. Lice infestations cause clinical symptoms such as clutter hairs, dandruff, hair losses, pruritus and anemia. Lice are usually found on the head, neck and sides of the body. In severe infestations, they may spread on the whole body on Equidae (11).

Bovicola (Werneckiella) ocellatus (Piaget, 1880) belong to the family Trichodectidae, in the suborder Ischnocera, order Phthiraptera, class Insecta (4, 12). According to Werneck (13), Piaget described this species as Trichodectes parumpilosus var. ocellata in 1880. Later, this species was described as Trichodectes parumpilosus ocellata by Kellogg in 1908; as Trichodectes ocellatus by Harrison in 1916; as Bovicola ocellata by Bedford in 1932; as Werneckiella ocellata by Eichler in 1939; as Damalinia (Werneckiella) ocellata by Hopkins in 1949. 
According to Moreby (9), this species was described as Werneckiella equi asini by Eichler in 1953.

There is no data that $B$. ocellatus were seen in donkeys, in Turkey. Morphological information will be given about the female of $B$. ocellatus detected on a donkey in Hatay province of Turkey in this paper.

The material of this article consisted of $B$. ocellatus samples collected from a donkey, which brought to the Ownerless Animal Care and Rehabilitation Center of the Hatay Metropolitan Municipality due to neglecting and senility. Hair losses, ruffling and opacity were observed on the donkey. A few louse specimens were detected on the hair shafts on the back of the donkey during the clinical examination. The louse samples were collected with a forceps and they preserved in a tube with alcohol $70 \%$. After that they sent to Department of Parasitology, Faculty of Veterinary Medicine, Selçuk University. The samples (2 93 nymphs) were cleared in $10 \% \mathrm{KOH}$ for 24 hours, rinsed in distilled water and passed through series of ethyl alcohol, mounted on the slides in Canada Balsam. After drying, they were examined and identified as B. ocellatus. No male of B. ocellatus was detected.
The head of female Bovicola ocellatus slightly rounded in front and it is flat or slightly concave in median. Marginal carina separated from each other by a narrow notch in the anteromedian. The mandibula well developed and notched in the apical. The antenna with three segments; the segment III is slightly longer than the others. The pre-antennal region is slightly shorter and narrower than the post-antennal region. The thorax is narrower and shorter than the head (Figure 1c). It is trapezoidal-shaped, narrowed to posterior. All the legs are weak and with a single claw. The first pair of legs shorter than the others pair and bent in the front. The abdomen is quite larger and longer than the head and thorax. The tergal and sternal plates are well sclerotized in the median, and with a short setae row posteriorly. Tergal plate of the second abdominal segment is thinner than the other tergal plates. The other tergal plates thickened from anterior to posterior. The paratergal plates well developed and became smaller towards to the posterior. The head length of female Bovicola ocellatus (Figure 1b) is $0.5 \mathrm{~mm}$, head width $0.52 \mathrm{~mm}$, thorax length $0.28 \mathrm{~mm}$, thorax width 0.35 $\mathrm{mm}$, abdominal length $1.32 \mathrm{~mm}$, abdominal width 0.87 $\mathrm{mm}$ and total length was $2.07 \mathrm{~mm}$.
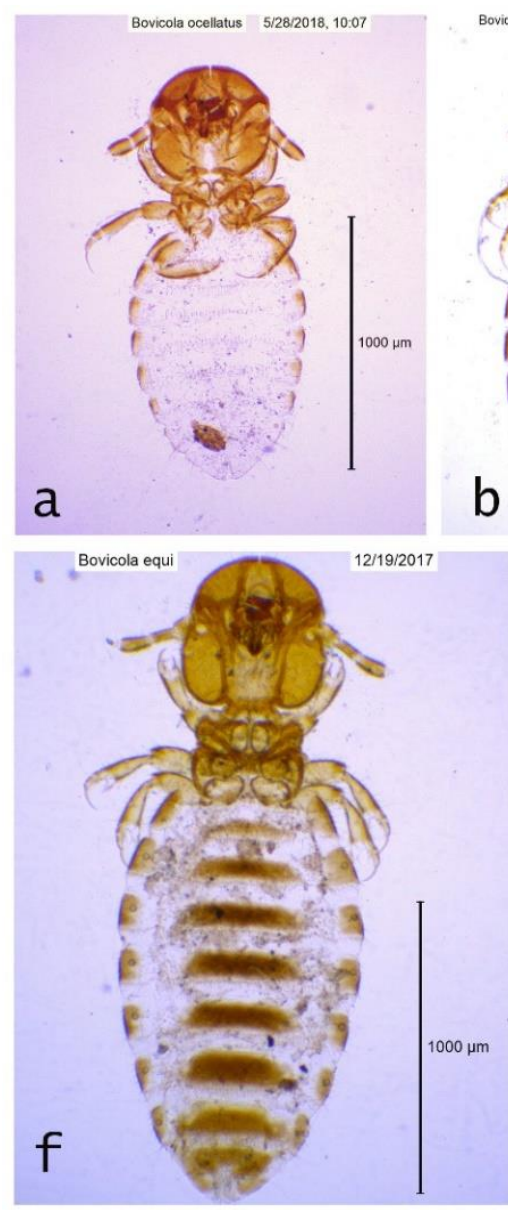
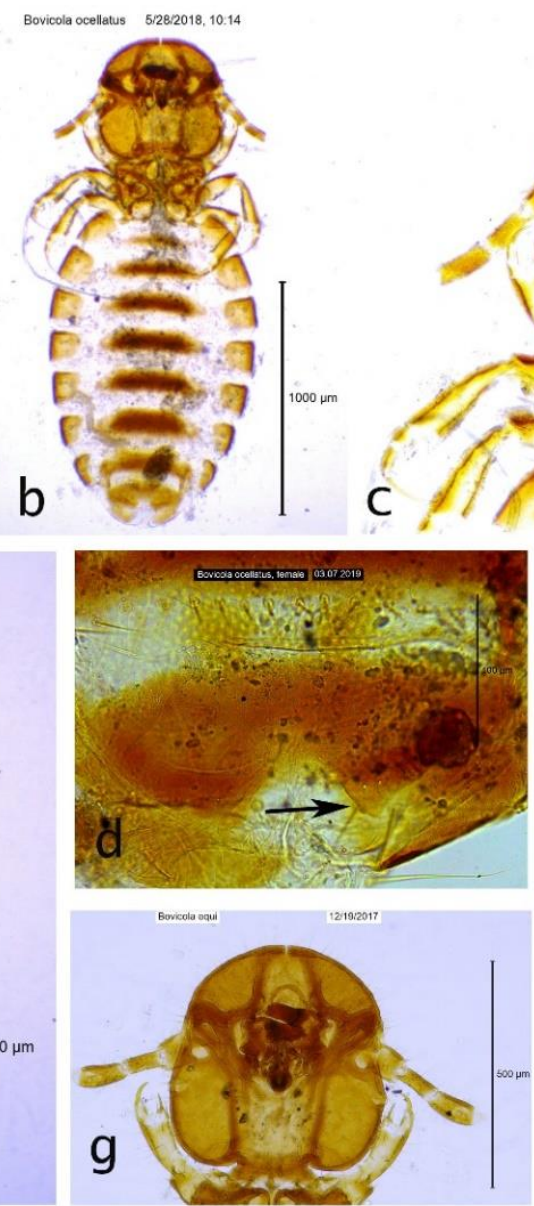
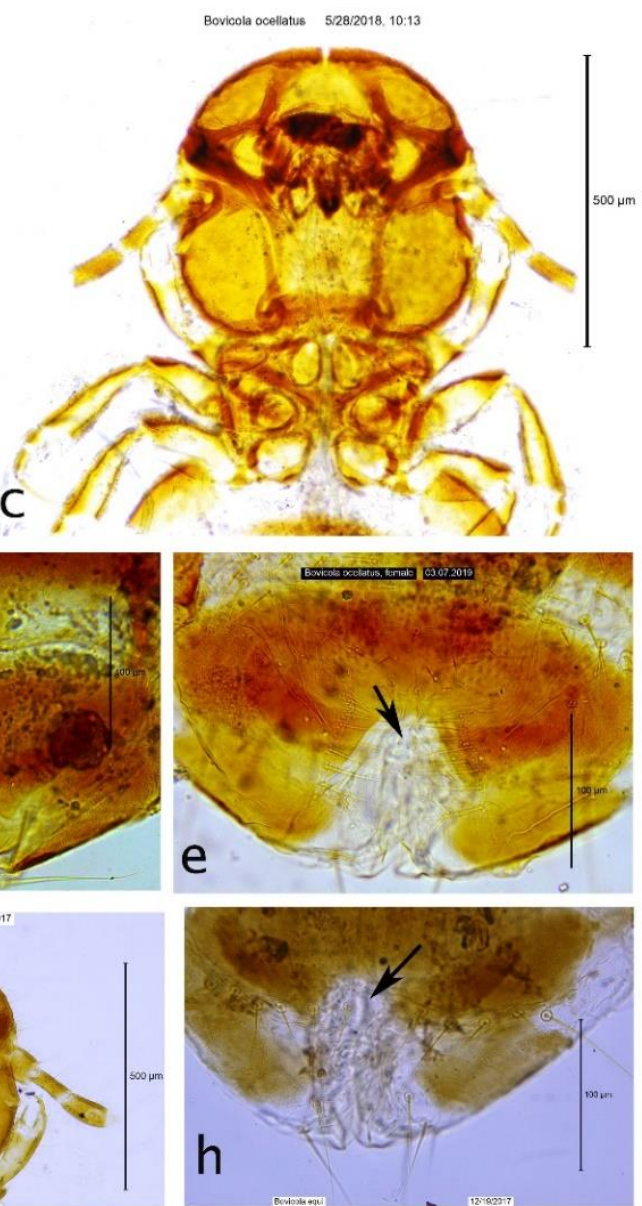

Figure 1. Bovicola ocellatus and Bovicola equi; a. Bovicola ocellatus, nymph III. b. Bovicola ocellatus, female. c. Bovicola ocellatus head, thorax, original. d. Bovicola ocellatus, female, lower part of tergite IX is pointed (arrow). e. genitalia apertura (arrow). f. Bovicola equi, female. g. head of B. equi h. post-vulval sclerite of B.equi 
There were three nymphs; two nymphs III (Figure 1a) and one nymph II. The nymph II is $1.14 \mathrm{~mm}$; the nymph III is $1.5-1.6 \mathrm{~mm}$. The nymphs are very similar to the adult, but tergal, sternal and paratergal plates of nymph II are not developed. The head of nymph III is concave in anteromedian, paratergal plates are weak developed whereas sternal and tergal plates not developed yet.

Moreby (9), stated that five specimens of B. ocellatus from zebra (E. burchellii burchellii), three specimens from horses (E. caballus) and 41 specimens from donkeys ( $E$. asinus) have been collected until that day. Only females of B. ocellatus detected, but male could not find. Firstly, Werneck (13) described male of B. ocellatus and gave its morphological characteristics. Later, he reported that he misidentified this species and corrected this species as $B$. aspilopygus (B. aspilopyga) (14). Although three males of $B$. ocellatus among the hundreds louse specimens taken from donkeys were reported, but there was no photo or explanation about the male of this species in that paper (3). It is known that B. equi (Denny, 1842), B. bovis (Linnaeus, 1758) and some other lice species reproduce parthenogenetically and produce male only during the rapid growth of the population (15). Probably for this reason, male of $B$. ocellatus could not found in this case.

Bovicola ocellatus can be separable easily from $B$. equi by its distinctive features. In female of Bovicola ocellatus; the head is widen, and flattened in anterior, the antennal cavity highly sclerotized, pleural plates are large, distinctive and well sclerotized, the post-vulval sclerites widen. In B. equi; the head is narrowed and rounded in anterior (Figure 1g), pleural plates are narrowed, moderately distinctive and weakly sclerotized (Figure 1f), post-vulval sclerites are different in shape (Figure 1h). Although tergite IX. is similar in both species, however in B.equi, it is oval whereas in B. ocellatus it is pointed posteriorly (Figure 1d). In B. equi, the genital opening relatively resembles to hourglass while bell-shaped in $B$. ocellatus (Figure 1e). B. ocellatus can be distinguished from $B$. aspilopygus and $B$. zuluensis by having vulvalpost scleritis, and from $B$. neglectus due to the narrower anterior marginal carina of the head, from $B$. zebrae due to with the absence of transparent circular areas in the tergite IX. and the wider paratergal plates (9).

Moreby (9) reported that; the mean of the head length of the females of $B$. ocellatus samples collected from zebras was $0.51 \mathrm{~mm}$, the abdominal width was $0.88 \mathrm{~mm}$, while the mean head length of the $B$. ocellatus samples taken from the donkey was $0.46 \mathrm{~mm}$, the width of the abdomen was $0.79 \mathrm{~mm}$, and the average total length of samples collected from both host species was measured as $2.12 \mathrm{~mm}$. In this study, the mean head length of two females of $B$. ocellatus collected from the donkey was 0.5 $\mathrm{mm}$, abdomen width $0.87 \mathrm{~mm}$, total length $2.07 \mathrm{~mm}$.
These measurements are consistent with those reported by Moreby.

According to Seguy (10), Harrison considered that $B$. ocellatus was a different species from $B$. equi whereas Keler stated that this species was the synonym of B. equi. In Turkey, we did not find any paper about the presence, prevalence and the other features of B. ocellatus as well as B.equi. Although, some authors $(7,8)$ reported that the Bovicola specimens found in horses and donkeys were considered as B. equi. Unfortunately, they $(7,8)$ did not publish any paper or figures of these specimens. In the light of the above information, some other authors $(1,6)$ have also stated that the species seen on horses and donkeys was $B$. equi. Therefore, it is unclear that the Bovicola samples collected from donkeys are B. equi or $B$. ocellatus. These findings and considerations can be mistaken, at least partly, and it is not possible to verify all this information today. On the other hand, only one article was found about B. equi was seen in horses in Turkey (5). However, there are no morphological characteristics and figures of $B$. equi in that paper.

In conclusion, this is the first report of B. ocellatus was seen on a donkey in Turkey. In addition, some morphological characteristics and figures of B. ocellatus and $B$. equi were explained here. Further studies should be needed to detect the male of $B$. ocellatus, as well as prevalence and biological characters of this species.

\section{Financial Support}

This research received no grant from any funding agency/sector.

\section{Conflict of Interest}

The authors declared that there is no conflict of interest.

\section{References}

1. Dik B (2015): Veteriner Entomoloji, Ders Kitabı, Selçuk Üniversitesi Basımevi, Konya.

2. Durden LA, Mullen GR (2019): Lice (Phthiraptera). 79106. In: Durden LA (Ed), Medical and Veterinary Entomology. 3rd ed. Academic Press, USA.

3. Ellse LS (2013): The epidemiology and control of the louse Bovicola ocellatus (Piaget) in donkeys. PhD Thesis, Bristol University, Bristol.

4. Emerson KC, Price RD (1981): Host-parasite list of the Mallophaga on mammals. Miscellaneous Publications of the Entomological Society of America.

5. Güleğen E , Çırak VY (2005): Bir at çiftliğinde Bovicola (Damalinia) equi (Linnaeus, 1758) enfestasyonu ve tedavisi. Turkiye Parazitol Derg, 29, 183-184.

6. İnci A, Yıldırım A, Dik B, et al. (2010): Current knowledge of Turkey's louse fauna. Turkiye Parazitol Derg, 34, 212-220. 
7. Merdivenci A (1965): Türkiye'nin entomolojik coğrafyast. 114-154. In: Unat EK, Yaşarol Ş, Merdivenci A (Eds), Türkiye'nin Parazitolojik Coğrafyası, Ege Üniversitesi Tıp Fakültesi Yayınları No: 42, Ege Üniversitesi Basımevi, İzmir.

8. Mimioğlu M (1973): Veteriner ve Tıbbi Artropodoloji. 343. Ankara Üniv. Vet. Fak. Yayınları, Ankara Üniversitesi Matbaasi.

9. Moreby C (1978): The biting louse genus Werneckiella (Phthiraptera: Trichodectidae) ectoparasitic on the horse family Equidae (Mammalia: Perissodactyla). J Nat Hist, 12, 395-412.

10. Séguy E (1944): Insectes ectoparasites:(mallophages, anoploures, siphonaptères). 393. 43 Faune de France, Paul Lechevalier et fils, Paris.
11. Taylor MA, Coop RL, Wall RL (2016): Veterinary Entomology. 209-210. In: Veterinary Parasitology. 4th ed. Wiley Blackwell, India.

12. Vas Z, Rékási J, Rózsa L (2012): A checklist of lice of Hungary (Insecta: Phthiraptera). Annls hist nat Mus natn hung. 104, 5-109.

13. Werneck FL (1950): Os malófagos de mamiferos. part. 2, Ischnocera (continuação de Trichodectidae) e Rhyncophthirina. Edição do Instituto Oswaldo Cruz.

14. Werneck FL (1956): A respeito de algunas malafagos de mamiferos. Revta bras. Biol, 16, 25-32.

15. Westrom DR, Nelson BC, Connolly GE (1976): Transfer of Bovicola tibialis (Piaget)(Mallophaga: Trichodectidae) from the introduced fallow deer to the Columbian blacktailed deer in California. J Med Entomol, 13, 169-173. 